\title{
Government-funded cultural industry projects models and issues research
}

\author{
Zhan Shaowen $^{1, a}$, Tian Bailu ${ }^{2, b}$ \\ ${ }^{1}$ Xi'an University Of Architecture And Technology, XiAn 710055, China; \\ ${ }^{2}$ Xi'an University Of Architecture And Technology, XiAn 710055, China; \\ aylyg100@126.com, b380750856@qq.com,
}

Keywords: cultural industry projects; government; sponsoring

\begin{abstract}
Government-funded cultural industry projects is key to ensure the sound development of cultural industry .Through adopting the method of literature and expert interview, on the basis of summarizing the existing sponsoring experiences ,analyzes the realistic difficulties of projects sponsoring and existing main problems, puts forward relevant suggestions.
\end{abstract}

\section{Introduction}

The height of the cultural industry has been the world attention .Recent years, China's policies are constantly shows that support for cultural industry to an all-time high。Constant attention to policy thinking for cultural industry, Make the cultural industry gradually move from the economic edge to the economic center。The eighteenth big report clearly put forward to promote culture industry become a pillar industry of national economy, Pointed out the direction for the development of cultural industry[1].Third Plenary Session of the 18th Central Committee put forward to speed up the perfect cultural management system and cultural production management system, Promote great development and prosperity of socialist culture[2].

Various areas in China are based on the development of the local characteristics take corresponding measures, In general can be summed up in the following "The government as the leading factor, the enterprise as the main body, market operation, society participation, through a big project". But the cultural industry as an emerging field, And because of its inherent weaknesses, Cultural industry projects always exist funds difficult problem in operation. Based on this, The government how to use a more scientific way of project funding eagerly anticipates the social capital, Enhance the level of operation of the project, In the process of the development of cultural industry is particularly important. Based on this, On the basis of combing government funding models, discussing the difficulties existing in reality and put forward relevant policy Suggestions.

\section{Government-funded cultural industry project modes}

The government's support measures of cultural industry can be divided into direct financing and indirect financing.

using special funds for funding.Early in 2008, the central finance set up the cultural industry development special funds. Allocated 1 billion yuan for the key support of cultural system reform, etc。2010,Enacted 《The cultural industry interim measures for the management of special funds》

(finance and teach[2010]81) , big cultural industry projects are the keys of funding. 2012, the Ministry of Finance enacted 《About the implementation of the spirit of the sixth plenary session of the 17 th to do a good job of financial support to cultural reform and development $\rangle$, Demand to increase financial investment in the field of culture and enacted about re issued 《The cultural industry interim measures for the management of special funds》 (financial cultural industry[2012]4 号) Redefine the direction and the way of rules. By the end of 14, Cultural industry development special funds already arranged 19.2 billion yuan, support more than 3300 projects, Strongly support the development of the cultural system reform and culture industry, to promote the structural adjustment of the national 
culture 、 rational allocation of cultural resources 、 to optimize the overall layout of industry development[3].

Fiscal funding. The government choice to the development of cultural industry can produce global long-term、 breakthrough the impact of cultural industries key projects. Funding for these projects directly, make culture invisible resources into productive forces.

The local government financial support. It's the spontaneous formation of the development model of local government, Here is usually refers to the government at the county level. The local cultural industry development almost solely responsible by the government because of lacking cultural enterprises. The government choice suitable projects according to the local actual situation, giving initial investment in packaging to make the project attractive for the government at a higher level and social support of money.

Bank credit support. Bank credit support is one of the main channels of funding sources in addition to the government financial support for cultural industry in China.2010, The central propaganda department、The ministry of finance、The ministry of culture.etc. nine ministries jointly issued 《About the financial support of cultural industry to promote the prosperity and development guidance》 (Bank[2010]94) clearly put forward, Commercial Banks should develop many kinds of loan models and diversified and multi-level credit products .2014, 《Opinions about deepening cultural and financial cooperation》 (cultural depatment[2014]14) Encourage Banks and financial institutions to play their respective comparative advantage makes the features of financial services products suited to the characteristics of the cultural enterprises, improve the credit management mechanism.

In the face of the cultural industry has gradually become the trend of the economic pillar, Corresponding government called on, commercial Banks will increase supporting for cultural industry year by year, increased lending to cultural enterprises。According to the China banking association 《China banking social responsibility report for 2014》 shows, 2014, cultural industry loans totaling 532.81 billion yuan, grow $12.3 \%[4]$.

The insurance industry supporting. Insurance is the basic means for risk management in the modern market economy, is an important part of the culture industry financing, it plays an indispensable role to promote the development of cultural industry projects 。 The government attaches great importance of insurance industry, In 2010 the ministry of culture and the circ jointly issued 《About insurance industry support the development of cultural industry about the work》

( $\operatorname{circ}[2010] 109$ ) Put forward the directions for insurance industry supporting the development of cultural industry: Developed the suitable types of insurance for the development of cultural industry. For the key cultural enterprises and the cultural industry projects to give positive support, etc. 2014 ,issued by the state council 《The several opinions on the speed up the development of modern insurance industry (country[2014]29) shows to develop cultural industry insurance, explore emerging insurance business such as acting, exhibition liability insurance.

According to the data, by the end of may 2012, Three pilot insurance institutions to launch related risks insurance service culture industry 111 key projects, involving 76 enterprises, the premium amount is 53.4926 million yuan, realize cultural industry risk coverage for 53.194 billion yuan[5].

\section{The problems existing in the government funding model}

In recent years, though, Promoting the construction of cultural industry projects in many areas of China has made many successful practices B But still exist many problems in the development process, hindering the development of cultural industry.

Culture industry financing difficulties, insufficient government input. At present, the cultural industry in our country at an early stage, the demand of funds is very big. For governments, Although 
government increasing each year for the culture industry investment, But relative to other industries and other countries is inadequate. And financial capital amplification effect is not obvious. For financial institutions, cultural industry is belong to the industry of the characteristics of the light assets, lacking of financial institutions approved mortgage collateral. And the cultural industry involves many industry categories, Different industry of cultural industry projects get funding is also different.

lacking of effective supervision and performance evaluation mechanism. About cultural industry of our country's government subsidies or funding policy, only rules on the application of methods and procedures, investment in the direction of the way and how much money. The government invested capital, It is difficult to take into account the application projects actual money demand, just to invest according to the declaration, The rationality of the amount is difficult to measure. In the process of project construction, can be seen often, at the beginning of the construction, devote to a large amount of money, trying to become bigger and stronger, In the process of finish, because of the lack of corresponding supervision mechanism, can be seen many problems, such as target makers and the executor of the project failed to communicate effectively, The cycle of the project is too long, etc, the result is far from the initial target when finished.

local government in the process of development of cultural industry facing the problems of lacking of money. Discussed in front, the local government to do the project early cultivation and packaging is an important factor to receive money, It's more obvious that good project usually attracted more investment. State and government give some projects the economic and policy support, Usually in the project produced under the condition of a certain size.

But some of the poorer areas as predominantly agricultural income county, The local finance income is not enough to give related cultural industry projects the proper support especially the necessary money at the begining of the projects. It is difficult to form a certain scale and receive more develop, Thus forming a vicious circle, Wealthier regions have sufficient fund to support the development of local cultural industry projects, These projects will bring more local fiscal revenue。But in the area of poverty, Because there is not enough money at the beginning of the project to support, more poor.

\section{Countermeasures and suggestions}

Introducing dynamic support mechanism to ensure the effectiveness of the money. The government for the investment in cultural industry project can consider to put all the money is not a one-off, But to put the funds invest in stages, According to the project actual operation situation in stages to devote to corresponding money for support, This can ensure the effectiveness of the investment.

Establish a professional asset appraisal mechanism and institutions. The government encourage guide cultural industry asset appraisal institutions and third party。 beside the financial institutions and cultural enterprises, provided culture industry project development outlook and cultural enterprise assets evaluation and other related services by the third party appraisal institution .Authoritative and reliable evaluation, Not only can solve effectively financing difficult question due to lack of heavy assets mortgage, can also supervise the cultural enterprises set up competitive consciousness, Makes the cultural enterprises take an active part in making their own value. to obtain the affirmation of the appraisal institution.

Promote the development of the insurance industry, to establish perfect financing guarantee mechanism. To speed up cultivating insurance market, Make up for the current absence of cultural market guarantee mechanism, Actively encourage insurance institutions to develop related cultural industry insurance products. Eventually form the cultural industry, asset appraisal, insurance, banking financial institutions, such as financial support, cultural industry standard operating procedures of the project, realize the development of cultural industry and cultural industry financing 
the virtuous cycle[6].

\section{References}

[1] $\mathrm{Hu}$ Jintao. Firmly march on the path of socialism with Chinese character,R. Beijing: The 18th National Congress of the Communist Party of China.2012.

[2] Xi Jinping. The Third Plenary Seesion of the 18th Central Committee of the Communist Party of China announcement, R. Beijing: The Third Plenary Seesion of the 18th Central Committee of the Communist Party of China.2013.

[3] Yang Liang. The ministry of finance issued 5 billion yuan culture industry development special fundsy,N. Guangming daily.2014-11-14 (10) .

[4] Wang Haoqiang. Build responsibility Banks, service national strategy,N.The financial times.2015-7-6.

[5] Wang Lianwen. The cultural industry insurance:Ideal plump, reality sense of bone ,N. Chinese culture.2013-4-4 (1).

[6] Yang Jingji. Our country culture industry financing model research ,D. Harbin university of commerce .2012:44-46. 